\title{
Menometrorrhagia Resistant To Progestin Treatment in a Secondary Infertile Woman with Pelvic Tuberculosis
}

Keywords: Tuberculosis; Pelvic tuberculosis; Infertility; Abnoma uterine bleeding

\begin{abstract}
In the underdeveloped and developing countries, tuberculosis endometritis is still an important infectious disease and community health problem. In cases with infertility, abnomal uterine bleeding resistant to progestin treatment and family history of tuberculosis, genital tuberculosis should be kept in mind.
\end{abstract}

\section{Introduction}

Genital tuberculosis, one of the oldest diseases in history, was first described in mid-eighteenth century and Tuberculosis bacillus (TB) was discovered in 1882 [1]. Although it was thought to be developing countries problem, after the HIV pandemics and increased immigration from developing countries to developed countries due to industrialization, TB has become world's problem. Five percent of the pelvic inflammatory diseases (PID) are associated with genital TB [2]. Genital TB can be primary or secondary.

Primary TB is that first focus that arises from pelvic organs and concomitantly pelvic lymph nodes have the infection. Secondary TB is the form that primary infection begins from somewhere else except pelvic region [3]. Secondary TB almost always has been seen after lung TB. Incidence of the secondary TB after the lung TB is 10\% [2]. Most affected organs of the pelvic are tubes (100\%), endometrium (50\%), ovaries $(20 \%)$, cervix (5\%), respectively while vaginal and vulvar disease are very rare [4-6].

One of the most common symptoms with genital TB is infertility (60\%) [7,8]; moreover, menstrual disorders and pelvic pain are not rare [11]. Menstrual disorder usually presents as amenorrhea or oligomenorrhea, menorrhagia, postmenopausal bleeding and dysmenorrhea are relatively rare clinical forms $[7,8]$. In some very rare cases, the disease presents with abdominal mass and/or ascites. And that can be very challenging to separate this situation from the ovarian cancer.

In this case presentation, we represent an endometrial TB case diagnosed during the investigation of abnormal uterine bleeding resistance to progestin therapy.

\section{Case Presentation}

A 33-years-old gravidity 2 parity 1 abortion 1 secondary infertile woman admitted to our hospital with complaint of menometrorrhagia, fatigue, fever and weight loss for 3 months. Before admission to
Journal of

\section{Andrology \& Gynaecology}

\author{
Emre Destegül ${ }^{2}$, Servet Gencdal ${ }^{1}$, Orcun Özdemir ${ }^{3}$ \\ and Murat Bozkurt ${ }^{1 *}$ \\ ${ }^{1}$ Department of Obstetrics and Gynecology, Kafkas University \\ School of Medicine, Kars, Turkey \\ ${ }^{2}$ Department of Obstetrics and Gynecology, Kayseri Education and \\ Research Hospital, Kayseri, Turkey \\ ${ }^{3}$ Obstetrics and Gynecology Clinic, Kozan State Hospital, Adana, \\ Turkey

\section{*Address for Correspondence} \\ Dr. Murat Bozkurt, MD, Assistant Professor, Kafkas University School of \\ Medicine, Department of Obstetrics and Gynecology, KARS, TURKEY; \\ Tel: +905322279072 +905056330044; Fax: 047422514 30; E-mail: \\ jindrmb@yahoo.com \\ Submission: 07 August 2014 \\ Accepted: 28 August 2014 \\ Published: 30 August 2014 \\ Reviewed \& Approved by: Dr. Ossama Elsaccar, Assistant \\ Professor of Obstetrics and Gynecology at West Virginia University \\ School of Medicine, USA
}

our hospital, patient had progestin therapy for 2 months, but no regression of complaints was obtained. Her medical history revealed that patient's husband had TB infection 16 years ago.

Physical examination showed nothing except vaginal bleeding associated with passage of clots. USG examination was normal and laboratory testing's revealed iron deficiency anemia. Given these findings and had a history of progestin therapy, endometrial biopsy was performed. Endometrial biopsy obtained granuloma structures with the multinuclear giant cells and epithelioid histiocytes. Patient chest $\mathrm{X}$-ray showed no evidence of pulmonary TB. Considering these findings, patient accepted as $\mathrm{TB}$ endometritis resistant to progestin treatment and received anti-TB therapy for six months (isoniazide, rifampicin, ethambutol, pyrazinamide). Three weeks after the initiation of therapy vaginal bleeding stopped. During the multidrug therapy, there were no adverse effects. At the end of six months of therapy, control endometrial biopsy performed and normal secretory endometrium was reported. The patient was free of disease for 18 months after treatment.

\section{Discussion}

Despite significant medical advances, TB is still a major factor of mortality from infectious disease [4]. Every year 8 million new TB cases are added to TB patient population and $95 \%$ of these patients from undeveloped countries [9]. Because of its different clinical manifestations, genital TB is still a major problem and difficult to diagnose for gynecologists. Genital TB can be latent for years after initial seeding and infection usually occurs by reactivation of organisms from systemic distribution of TB bacillus.

Diagnostic tools vary from physical examination to isolation of TB bacillus. Although physical examination is very importance for diagnosis of genital TB, it may reveal nothing [3]. Chest x-ray is the another tool to search primary or secondary TB focus but normal 
Citation: Destegül E, Gencdal S, Özdemir O, Bozkurt M. Menometrorrhagia Resistant To Progestin Treatment in a Secondary Infertile Woman with Pelvic Tuberculosis. J Androl Gynaecol. 2014;2(2): 2.

chest $\mathrm{x}$-ray doesn't exclude the TB as about $75 \%$ of patients have normal chest $\mathrm{x}$-ray [5].

Raut et al. found the Mantoux test showed a sensitivity of 55\% with a specifity of $80 \%$ in female genital TB [10]. Endometrial curettage and demonstration of $\mathrm{TB}$ bacillus is also important diagnostic procedure for genital TB. Tasova et al. reported the isolation of bacillus is the certain diagnostic criteria for genital TB [11]. Acid resistance staining, granulomatous infectious findings in histological specimens, positive Mantoux test, clinical findings and symptoms associated with $\mathrm{TB}$ and response to anti-TB treatment are described as minor diagnostic criteria [11].

In the present case report, there were minor criteria including $\mathrm{TB}$ related clinical findings and symptoms (fever, weight loss, fatigue), granulomatous inflammation in histopathologic examination of endometrial specimen and response to anti TB treatment.

There are limited data for optimal medical therapy duration of genital TB. But the guidelines recommend at least 6 months anti TB therapy with multidrug combination [12]. In the cases resistant to anti-TB treatment, total abdominal hysterectomy and bilateral salpingo-oophorectomy is the surgical choice. It is important to give anti- TB treatment for at least 6 weeks before surgery because of the reduction of perioperative complications [13].

In conclusion, especially in undeveloped and developing countries, young patients with infertility, family history of TB and abnormal uterine bleeding resistant to progestin treatment, genital TB should be kept in mind.

\section{References}

1. TW Chow, BK Lim, S Vallipuram (2002) The masquerades of female pelvic tuberculosis: case reports and review of literature on clinical presentations and diagnosis. J Obstet Gynaecol Res 28: 203-210.
2. A Mantovani, M Pelagalli, C Bracalenti, G Pierandrei (1998) Postmenopausal endometrial tuberculosis. A clinical case. Minerva Ginecol 50: 93-96.

3. Ülgenalp İ, Orhon E. Kadın genital tüberkülozu. (1996) In: Kişnişci HA, Gökşin E, Durukan T, Ostay K, Ayhan A, Gürgan T, Önderoğlu LS. Temel kadın hastalıkları ve doğum bilgisi. Güneş Kitabevi, Ankara. 634-641.

4. Hassoun A, Jacquette G, Huang A, Anderson A, Smith MA (2005) Female genital tuberculosis: uncommon presentation of tuberculosis in the United States. Am J Med 118: 1295-1296.

5. Saracoglu OF, Mungan T, Tanzer F (1992) Pelvic tuberculosis. Int J Gynaeco Obstet 37: 115-120.

6. Nogales-Ortiz F, Tarancon I, Nogales FF Jr (1979) The pathology of female genital tuberculosis. A 31-year study of 1436 cases. Obstet Gynecol 53: $422-$ 428.

7. Weerakiet S, Rojanasakul A, Rochanawutanon M (1999) Female genital tuberculosis: clinical features and trend. J Med Assoc Thai 82: 27-32.

8. Adewole IF, Babarinsa IA, Akang EE, Thompson MO (1997) The value of routine endometrial biopsy in gynaecological practice in Nigeria. West Afr J Med 16: 242-245

9. C Dye, S Scheele, P Dolin, V Pathania, MC Raviglione (1999) Global burden of tuberculosis: estimated incidence, prevalence, andmortality by country. JAMA 282: 677-686.

10. VS Raut, AA Mahashur, SS Sheth (2001) The Mantoux test in the diagnosis of genital tuberculosis in women. Int J Gynecol Obstet 72:165-169.

11. Taşova Y, Saltoğlu N, Mıdıkıı D, Kandemir Ö, Aksul HSZ, et al. (2000) Erişkinde 98 ekstrapulmoner tüberküloz olgusunun değerlendirilmesi. Klinik 13:17-23.

12. Blumberg HM, Burman WJ, Chaisson RE, Daley CL, Etkind SC, et al (2003) American Thoracic Society/Centers for Disease Control and Prevention/ Infectious Diseases Society of America: treatment of tuberculosis. Am J Respir Crit Care Med 167: 603-662.

13. AM Sutherland (1980) Surgical treatment of tuberculosis of the female genital tract. BJOG 87: 610-612. 